\title{
POLITICS, PEER REVIEW
}

\section{AND PERFORMANCE MANAGEMENT \\ IN AFRICA: A PATH TO CREDIBLE \\ COMMITMENT FOR NIGERIAN POLITICIANS?}

\author{
Okechukwu Marcellus Ikeanyibe \\ Ph.D., Professor, Department of Public \\ Administration and Local Government. \\ Address: Faculty of the Social Sciences, PMB 002, \\ University of Nigeria Nsukka, Enugu State, Nigeria. \\ Email: okey.ikeanyibe@unn.edu.ng

\section{Josephine Obiorji} \\ Ph.D., Lecturer, Department of Public \\ Administration and Local Government. \\ Address: Faculty of the Social Sciences, PMB 002, \\ University of Nigeria Nsukka, Enugu State, Nigeria. \\ Email: Josephine.obioji@unn.edu.ng
}

\section{Nnabuike O. Osadebe}

Ph.D., Lecturer, Department of Sociology/Anthropology,

Address: Faculty of the Social Sciences, PMB 002,

University of Nigeria Nsukka, Enugu State, Nigeria.

Email: nnabuike.osadebe@unn.edu.ng

\section{Chuka E. Ugwu}

Ph.D., Lecturer, Department of Public

Administration and Local Government.

Address: Faculty of the Social Sciences, PMB 002,

University of Nigeria Nsukka, Enugu State, Nigeria.

Email: chuka.ugwu@unn.edu.ng

\begin{abstract}
The study examines the application of performance management (PM) to politics in the African context using Nigeria as a focus. It argues that PM will yield better results if it focuses on ways to improve and stabilize the results of politics based on the notion of politics-administration dichotomy and the leadership role of the political class in that relationship. The relevance of some key elements of the Common Assessment Framework (CAF) such as the role of leadership, peer review, self-assessment, competitiveness and comparative learning and innovation are investigated as elements of performance management at this level. Documentary data based on the implementation of the African Peer Review Mechanism (APRM) and evaluation of the application of performance information in relation to those critical roles of politicians were
\end{abstract}


analysed. The authors found that although measures aligning with the CAF model of PM are in place, politicians remain poorly committed, inconsistent and irregular in submitting and using performance information. The study suggests strengthening PM at the political level of governance through energised support for an African Peer Review Mechanism framework and an international push for sustained application of peer review and results of various global performance indexes in dealing with African countries.

Keywords: performance management; peer review; politics-administration dichotomy; common assessment framework; African peer review mechanism; Nigeria.

Citation: Ikeanyibe, O.M., Obiorji, J., Osadebe, N.O. \& Ugwu, Ch.E. (2020). Politics, Peer Review and Performance Management in Africa: A Path to Credible Commitment for Nigerian Politicians? Public Administration Issues, no 5, (Special Issue I, electronic edition), pp. 35-58 (in English); DOI: 10.17323/1999-5431-2020-0-5-35-58

\section{Introduction}

Controversy on the nature of the relationship between elected politicians and bureaucratic career officials has raged since the emergence of the study of public administration in the 19th century (Verheijen, 2000). The classical administrative thinking provided ground for the perception of the administrative system as separated from the political system (Heady, 1984). Max Weber, Woodrow Wilson and other eminent classic administrative theorists envisaged a role differentiation often qualified as politics-administration dichotomy among these two groups of government personnel. Although other models explaining politics-administration relations have attempted to supplant the dichotomous model over the years, they have generally maintained that the political class is the senior partner in this relationship, with the responsibility to structure, empower and control the administration. Svara $(2001 ; 1985)$ considered the politics-administration dichotomy model as desirable in providing a normative base for assessment of appropriateness of behavior. In spite of the relevance of projecting the notion of integration and overlapping in this relationship, there is evidence that the tension between the two classes of government officials continues to be significant (Ugyel, 2017), to the extent that only a notion of separation can better explain and place the responsibility and performance of groups of officials in government. Although the key organs and institutions of government, namely the legislature, the political executive, the judiciary and the administrative institutions should work harmoniously to enhance government performance and effectiveness, it is important that efforts to improve government functioning should be properly channeled to address faults where they lie strongly. Nevertheless, what is usually the case is that the bureaucracy is framed and blamed for public service failure. Thus, more often than not, efforts to make government more efficient and effective focus on reforms directed at bureaucratic agencies and personnel, neglecting the governance and leadership role of political officials. For instance, despite recognising the fact of the 
logical impossibility of having a perfect social organisation as a result of the self-interest of rulers, Miller (2000), like many scholars, propounds a solution largely hinged on the bureaucratic structure and process. Taking a cue from Holmstrom's (1982) analysis of an impossibility result arising from moral hazard in teams (Moral hazard refers to a self-interested incentive to do something that detracts from the efficiency of the social organization) or what has come to be known as Hostrom's impossibility theorem, Miller (2000) has argued that "progressive ideology of separation of politics and administration serves the same efficiency-enhancing role in public administration that Holmstrom argued for separation of ownership and control in private administration". Miller has directed his attention on how best to control the bureaucrats - through a hierarchical control system of the principal-agent model or through developing a neutrally based bureaucratic control based on professional expertise that helps to hold the self-interest of both the politicians and the administrators in check. He has argued that "the characteristics of Weberian bureaucracy, including rational/legal constraints and autonomous professional norms, serve to insulate bureaucrats from efficiency-undermining political pressures" (Miller, 2000, p. 289). However, chronic problems of unproductive public administration cannot be solved merely by traditional bureaucratic structure and processes alone (Kalfa \& Yetim, 2018) or the whole of government approach which beclouds the role of each group. Efforts to improve performance management in the public sector have seen the adoption of some private sector managerial tools, as in the New Public Management (NPM), Total Quality Management (TQM) and Performance Management (PM) approaches that provide more measurable, practical strategies. Despite the introduction of these private sector approaches, their application has often failed to achieve optimal results for the same reason of skewed attention on the bureaucratic agencies and career employees, neglecting the important need to also deal with how to incentivise the performance of political officials. In this vein, it is needful that the idea of performance management should be re-examined in the light of politicsadministration dichotomy to properly place issues of performance, especially in the African environment, where politics remains critical to virtually every activity of government.

Jacobson (2006) averred that many studies on politics-administration relationships stop with the analysis showing whether there exists a separation, integration or overlap in terms of various role specifications. Similarly, Azunu (n/d) remarked that the politics-administration relationship debate has mostly been about whether or not politics can be separated from public administration and what key factors affect the relationship between these two intervening fields. There is scarce scholarly focus in this field on the performance of the political class in this relationship as the norm has usually been to focus attention on reforming the bureaucracy with its attendant dysfunctions and negative attributes or the whole of government perspective. In most polities, the assumption is that non-performing political officials will be voted out in the next round of elections or the fact that civil society actions will keep the politicians in check, hence little need to bother about how their performance should be managed. But it is clear 
that such democratic values and processes are yet to be strongly institutionalized in Africa and some developing democracies. Various scholars of African politics employ various concepts such as patrimonialism (Bratton \& Van de Walle, 1994), primordialism, ethnicity, nepotism, and corruption (Nnoli, 2008), Prebendalism (Joseph, 1987), politics of the belly or stomach infrastructure (Bayart, 1993; Osaghae, 2003), and instrumentalisation of informal politics (Chabal \& Daloz, 1999) among others, to describe the nature of politics in Africa. Apparently, the fundamental character of African politics is that the state has not been liberated from the constituent societies and to the extent that it mars the functioning of modern institutions (Ekeh, 1975). There is no doubt that activities at the political level tainted with these negativisms tend to seep down entire government institutions and impinge on good governance.

Performance management in Africa should thus, as a matter of priority, deal with the context of politics that constrain the task of state building and policy direction as much as focus on reforming administrative institutions. It is rather a case of healer heal thyself. The puzzle then is how efforts to improve government performance using the performance management (PM) approach could be applied to political officials in the African context. Andrews (2014, p. 3) has opined that "within the public sector, performance management may also be useful to politicians". This opinion has not received adequate attention. PM has usually been understood in terms of the traditional emphasis on managing inputs (budgets and staff) and processes (rules and structures) (Andrews, 2014) but not necessarily on the enablers of inputs such as leadership and politics. This calls to question the need to re-examine how the contextually specific assumptions underlying performance management could be understood in relation to the political officials in government in the African context based on the notion of politics-administration dichotomy and the assumed leadership/governance role of the political class in that relationship. The following research questions further define the research focus. (1) How does the role of political officials affect the performance of government in Africa? (2) How could the specific assumptions of performance management be understood in relation to the political class in the African context?

The study contributes to the understanding of the theoretical and practical underpinnings of performance management of the political class in Africa based on the politics-administration dichotomy model. The CAF model of PM is used for the study. It stipulates features such as peer review, self-assessment, competitiveness and comparative learning and innovation as mechanisms that could help to evaluate and manage the performance of the political leadership of countries. Peer review in particular is the notion that governments whether global, regional, national or local are peers of one another and their conduct can be reviewed by mechanism set up for such purpose (Amoda, 2012). We used a desk review and meta-analysis approach for the study. We have applied critical analysis of extant sources such as documentary data in official publications including reports of the African Peer Review Mechanism's continental and country reports, and official government reports and those of other international agencies such as the Mo Ibrahim Index of governance for Africa. 


\section{Politics-administration relations model} and role distinction in government

The perception of public administration as being separated from politics came through a vigorous effort made to give existence to public administration discipline, and clearly distinguish roles in government despite obvious integration and overlap. According to Martin (1988, p.632), the leading assumption that inspired the proponents of politics-administration dichotomy school was that "politics and administration work best as independent variables, capable of being improved in isolation without endangering or interfering with the other side". The key proposition here is that the role of the politician as the senior partner in government is restricted to setting the task for administration and that of administration devoted to policy execution (Wilson, 1887). But it would be a misconception to perceive the two 'independent variables' as a 'constant' (Jacobsen, 2006, p. 304). Indeed, most of the proponents of the model did not actually intend a full separation, but were concerned with how to strengthen the independence of administrators and to protect them from political interference (Rabrenovic, 2001; Peters, 1987). The implication of a strict separatist perspective would entail that once policies are decided by the politician, the inability to produce the desired results is as a result of poor execution. This paves the way to what is perceived as a bureaucratic system of public administration that sees public administrators as managers of public organizations with greater autonomy from politics (Rouban, 2003; Sancino, Meneguzzo, Braga \& Esposito, 2018) hence, leading to the framing and blaming of the administrative system in most issues of performance failure in government. Apparently, this disregards the fact that executive political officials in most climes head various public organizations and could actually be seen as the de facto public managers, and that their roles are critical to the performance of even the administrators and public organizations.

Other perspectives have emerged over the years to explain the politics-administration relations, but often fall into the same trap of framing the administrative system for largely being responsible for poor performance of government. A number of scholars assert that an interaction exists and is necessary, and recognise that "if the relations between the two are co-operative, the legitimacy of government will be reinforced, while hostile and non-co-operative behaviour will lead to ineffective governance, with a negative effect on levels of legitimacy" (Rabrenovic, 2001, p.11). Jacobsen (2006) averred that if the relationship between the political and the administrative sphere is perceived as a variable, it opens up for the possibility that it may vary among contexts and over time. For instance, the political school (Demir, n/d.; Lipsky, 1980; Federickson, 1980) rejected the separation option and proposed overlapping and integrated relations. The school asserted that administrators are involved in politics, possess technical knowledge and engage in policy making and advisory roles, thus, leaving very little power with politicians. In effect, public administration appears to be superior to politics in the allocation of government actions. This view obviously intensifies the framing of the bureaucracy and hence the need for constant reform and control of the administrative system. Some scholars (e.g. Heady, 1984) proposed an in- 
strumental view, somewhat related to the principal-agent relations that perceives public administration or the administrative system as an instrument or agent of the politician. These perspectives, such as the New Public Management, see the administrators as managers of government agencies responsible for the definition and the attainment of goals, as well as for the good management of financial and human resources (Sancino, Meneguzzo, Braga \& Esposito, 2018; Pierre \& Peters, 2005). Many of these perspectives assert administrative autonomy as if an instrument or agent is a standalone aside 'the workman' using the instrument or the principal backing the agent. Miller (2000), for instance, argues that even the politicians' self-interest can be kept in check by adopting the correct model of politics-administration separation. He has argued that "the characteristics of Weberian bureaucracy, including rational/legal constraints and autonomous professional norms, serve to insulate bureaucrats from efficiency-undermining political pressures" (Miller, 2000, p. 289). Taking a cue from Holmstrom's (1982) analysis of an impossibility result arising from moral hazard in teams, Miller (2000, p. 325) submits that "progressive ideology of separation of politics and administration serves the same efficiency-enhancing role in public administration that Holmstrom argued for separation of ownership and control in private administration". Apparently, Miller believes that if a bureaucracy possesses autonomy, expertise, professional ethics and is properly trained, even the moral hazard arising from the politicians' self-interest could be put in check. For him, the principal agency model, with hierarchical control of bureaucratic agents by their democratic principal, was not essential to engender effectiveness of government as propagated by such scholars like Finer (1941). But like Freidrich (1940), Miller believes that "to be efficient, governments should and sometimes do devise constitutional checks and balances that constrain rather than unleash popular democratic control over bureaucracy". We are yet to see this ideal work, especially in Africa. The view has rather encouraged the framing of the bureaucracy and its constant reform at the expense of the role of the politicians. The public administration system therefore remains conceptually the centerpiece of government with scant attention paid to how the role and performance of the politician could be managed as well as distinguished from reforms focusing on the administrative agencies and their control.

Whatever the theoretical perception of the nature of the relationship between politics and administration (separation, interaction, instrumental principal-agent or otherwise), the common denominator has been the acknowledgement that the political class is the senior partner in the politics-administration relations and has the responsibility to structure, lead and control the administrative system. According to Panday (2017, p. 2),

Political control is possible on the grounds that bureaucracies are created by the elected institutions who design the structure in such a way that it facilitates their control of it. Politicians always remain vigilant on the activities of the bureaucrats in order to make sure that information is not distorted. Moreover, activities of bureaucrats are subject to sanctions and rewards if they fail to attain the desired result. 
The implication of this power of control, as noted before, is the framing of the bureaucracy and the concentration of reforms on its structure and processes, while neglecting issues of political leadership and governance and the reforms they engender.

The Performance Management approach proposed improving public programmes and agencies by developing and adopting clear goals, measuring employee performance and providing rewards accordingly. The emphasis often is on the administrative agencies and their employees. Cook (2004, p. 604) avers that "'management' (or its corollary, administration mine) has historically taken 'the organization' as its basic unit of analysis and action. This is often a tacit assumption or, if not, one that passes unremarked, as in the very conflation of MOS - 'management and organization studies'". Nevertheless, performance management in government should focus on both classes of officials based on the thesis of politics-administration dichotomy, so as to properly address the failings of each. The 'pathological degeneration' of public administration cannot be resolved "when authoritarian and/or politicised governments pursue particular instead of general interests" (Cook, 2004, p. 604). Politicians remain strategic to the empowerment, enablement and control of the administrative system. They provide political guidance through policy leadership and legislative oversight (Demir, n/d). Policy leadership links elected officials to citizens, while legislative oversight links them to public administrators. When the focus of performance management is largely on the administrators and administrative agencies, the politicians appear to become self-righteous and impeccable. It is therefore important to investigate strategies for gauging the performance of politicians in government which is critical but has been neglected in Africa. In the next section, we conceptualise performance management and a framework for its applicability to the political officials in government.

\section{Performance management (PM) framework and its applicability to politicians}

Although ways of appraising and rewarding employees have long existed (Williams 2003), the term 'performance management' (PM) was not utilised until the 1970s (Armstrong and Baron, 2005). As a reform movement, it was a strand of the New Public Management (NPM) reform that began in most western countries as part of the neoliberal movement that began in the late 1970s. PM is not precisely defined, nor does it cover a set of common practices based on an explicit, recognised framework (Maurel, Carassus, Favoreu \& Gardey, 2014). However, one thing is important: PM is a tool to improve performance in the whole of an institution or equally in a specific part of it. Andrews (2014) pinpoints three steps that are likely to be included in any performance management programme. First, policy-makers and/or managers or the body developing a PM initiative need to select a relevant set of performance indicators which can be used in two ways to analyse an organization's achievements - through time and/or in comparison with other relevant organizations. Next, they must define expected standards of attainment on those indicators in relation to benchmarks, such as minimum standards or initial baseline 
performance. Then they apply appropriate tools of managerial control to incentivise managers and employees to meet the expected standards. Boyne (2010) operationalised these into three interlinked elements, namely, target-setting, performance measurement, and, rewards and/or sanctions. These principles are hard to effect at the level of politics because the politician or the manager is the target setter, the one that measures and rewards/sanctions. More often than not, they appear to be outside the PM framework in relation to the control of their own performance.

Andrews (2014) distinguished two levels of application of performance management in the public sector: (1) the micro level or within public organisations and (2) the policy field level or across sets of public organisations. The two levels have some specificity in the expectations of those whose performance should be managed and instruments required for achieving results. At the micro organisational level, usually the economic approach is emphasised. Models based on this normally use the input-output relation as the basis for performance management. Boyne's (2010) elements for managing performance, namely target-setting, performance measurement, and, rewards and/or sanctions can seamlessly be applied at this level. The input-output framework is often measured in monetary terms; however, for application to the public sector, it has been modified to the input-output-outcomes model (IOO) (Maurel, Carassus, Favoreu \& Gardey, 2014, p. 25), which "provides a wider range of criteria for the evaluation of organizational performance.... Outcomes are measured by non-financial indicators that represent the social benefits deriving from the action, whereas outputs designate activities that will not necessarily lead to outcome-type results". The framework integrates economy, efficiency and effectiveness as the common indices of performance management. Andrews (2014, p. 3) observed that the economic framework has usually been understood in terms of the traditional emphasis on managing inputs (budgets and staff) and managing processes (rules and structures). The advantage of applying PM at this level is the presence of a manager who is responsible for overseeing the performance of others by setting targets, measuring output/outcome and rewarding or sanctioning. However, it is less holistic than what performance management should be in government as it focuses on employees and processes within the organization, neglecting actors outside the administrative organisation or those that try to ensure the performance of others such as managers, legislators, political executives and so on. The employees of public organisations (the administrative system as separated from the politicians) based on the traditional conception of politics-administration dichotomous relations bear the brunt of performance management efforts in this manner. Nevertheless, "performance management is not a mechanical process that can be set in motion and left to run on auto-pilot. Benefits are not realized without engaged leadership and a strong organizational commitment to changing inadequate decisionmaking processes, structures, and a culture of complacency" (National Performance Management Advisory Commission, 2010, p. 6).

Maurel, Carassus, Favoreu and Gardey (2014, p. 24) disclose that a review of the literature on performance management models in public organizations shows that authors' visions of public performance are incomplete. Their study tried to enrich the literature "by going beyond a partial vision of organisational performance to integrate the politico-environmental specificities of the public 
sector". This is akin to Andrews' policy field level mentioned above. Indeed, the ultimate goal of PM at this level is good governance perceived here in a stricter sense of politics and policy ownership, although governance is all embracing (incorporating roles at both the political policymaking and organisational implementation levels). Maurel, Carassus, Favoreu and Gardey (2014, p. 24) described this approach as the "partnership" framework of PM, and aver that it is "a more focused stakeholder orientation (models where citizens participate directly in the process of assessing and measuring the performance of government)". PM at this level traditionally consists in the social capital of citizens and civil society actions. Adsera, Boix and Payne, (2003, p. 447) equate this with good governance, which is a function of the extent citizens can hold political officials accountable for their actions. In particular, it shows that as both democratic institutions are established and the information citizens have about both the state of the world and the policy maker's decision increases, the space for rent appropriation shrinks. To support this citizens' check, which is weak in the African context, most governments through international, regional and national initiatives have come to appreciate the importance of peer review, self-assessment and competition as instruments of performance management. Peer review is the notion that governments, whether global, regional, national or local, are peers of one another and their conduct can be reviewed by mechanisms set up for such a purpose (Amoda, 2012). While peer review has been a strong instrument of performance management, for example in academic circles, some analysts view it as practically unrealistic and politically impossible in Africa (see Tawfic, 2004, p. 5). Tawfic has quoted one of his research interviewee as saying: "It is really a bizarre idea to have those heads of states and their nominated persons sit around a table to say who is behaving himself and who is not". Despite this skepticism, peer review and global ranking of countries have come to be perceived by nations as a viable instrument for measuring performance and leveraging efforts to improve on different governance issues. A typical model of the partnership framework is the Common Assessment Framework (CAF), a total quality management tool jointly developed by a working group of the Innovative Public Services Group (IPSG) to promote exchanges and cooperation towards modernizing government and public service delivery in European Union member states (Osterreich, 2006). CAF is based on a competitive, dynamic model that concerns all the political and economic fields. As a tool of performance management, CAF is based on the premise that excellent results in organisational performance, citizens / customers, people and society are achieved through leadership driving strategy and planning, people, partnerships and resources, and processes. For a manager, it is not just a tool for the manager which is applied to his/her employees, or which is applied to the membership of public organisations by a politician. As a peer review and self-assessment tool, it aims at covering those outside the traditional performance management system of the organisation; hence the manager can also evaluate his or her own performance, or outside peers could do so. In the CAF, peer review, self-assessment, competitiveness, comparison and learning are particularly encouraged through established performance awards such as the Europe Quality Award to encourage competition (Kalfa \& Yetim, 2018, p. 4). The Figure below illustrates the elements and criteria for PM in this model. 


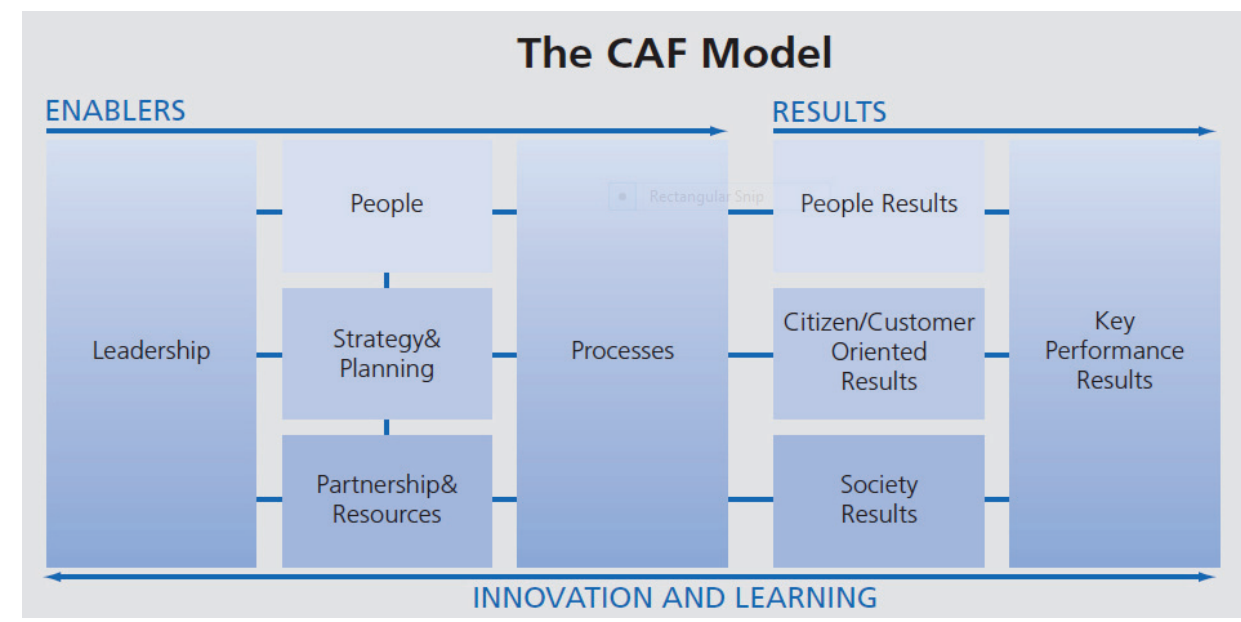

Source: Osterreich (2006, p. 5).

PM in the CAF model consists of two important parts - the enablers and the results. The enablers are meant to lead to the attainment of results as the arrow shows. In all, performance is measured against nine assessment criteria - five enablers and four results, namely, leadership, people, strategy and planning, partnership and resources; processes, people results, citizen/customer oriented results, key performance results. Thus, leadership, which at the micro level appears to be outside the traditional PM framework, is primary among the enablers in this framework. The nine criteria are departmentalized in the columns, which signify that despite their composite nature, a separation could be made between the enablers and the results, as well as each criterion/criteria as encapsulated in the columns. Osterreich (2006, p. 5) stipulated that "CAF has been designed for use in all parts of the public sector, applicable to public organisations at the national/federal, regional and local level". He described the framework as holistic, which "does not simply mean that all aspects of the functioning of an organisation are carefully assessed but also that all the composing elements have a reciprocal impact on each other" (p. 6). This implicitly recognises that the cause-effect relation between the enablers (causes) and the results (effects) also apply to different groups of personnel in government and their roles. For instance, each criterion of the enablers, such as leadership, is solely significant and should be optimal to expect the required performance of other components. Indeed, leadership drives people, strategic planning or policy, resources and partnership, as well as processes. If the political class (leadership) does not perform effectively, efforts to reform the bureaucracy will likely remain sub optimal. Another significant feature of CAF is the incorporation of peer review, innovation and learning from others (see the bottom part of the figure) as essential in PM.

Indeed the introduction of the APRM is recognition by African governments that self-monitoring and review will encourage countries to improve their standards of governance and provide a mechanism for both the people of the continent and outsiders to benchmark their performance (Chukwumerije, 2006). Subsequent sections will provide a background of politics in Africa and examine the extent to which these elements of CAF apply. 


\section{Brief background on politics in the African context}

Africa is home to 54 countries, many of which have adopted various political and public administrative systems usually imitated from ex-colonial western countries. These administrative systems have in many instances been altered through incessant global reforms imitated or imposed as conditionality by global financial, governance and aid-donor institutions such as the World Bank, the International Monetary Fund (IMF) and United Nations (UN) development agencies. With the exception of a few of these countries that are believed to have recently made some remarkable improvements in their economies and public administration systems (Zoogah, Peng \& Woldu, 2015; Hoskisson, et al.; McKinsey Global Institute, 2010), many of the African countries are still bedeviled with widespread public administration ineffectiveness and poor performance of public officials that largely affect the entire development superstructure (Ikeanyibe, 2017; Ayee, 2005; Hyden, 1983; Joseph, 1997; World Bank, 1993).

Many scholars have tried to rationalise the causes of Africa's slow development and ineffective public administration based on analysis of the sociocultural, historical, psychological, leadership and many other frameworks (Zoogah, Peng \& Woldu, 2015). For instance, Ekeh (1975, p. 92) aptly integrates some of the perspectives in this argument such as the historical, socio-cultural, psychological and leadership perspectives when he posits that the experiences of colonialism in Africa have led to the emergence of two publics instead of one:

At one level is the public realm in which primordial groupings, ties, and sentiments influence and determine the individual's public behavior. I shall call this the primordial public because it is closely identified with primordial groupings, sentiments, and activities, which nevertheless impinge on the public interest .... On the other hand, there is a public realm which is historically associated with the colonial administration and which has become identified with popular politics in postcolonial Africa. It is based on civil structures: the military, the civil service, the police, etc.

Ayee (2005) identified excessive politicisation, lack of accountability and representation, inability to promote the public interest and authoritarian tendencies. Other scholars (Chabal \& Daloz, 1999; Von Holdt, 2010) remark that the state in Africa remains a pseudo-western facade that disguises the fact that neither politics nor state institutions have been emancipated from society or rather societies and have therefore never been institutionalised. Various concepts are employed to describe politics in the African context: patrimonialism (Bratton \& Van de Walle, 1994), primordialism, ethnicity, nepotism, and corruption (Nnoli, 2008), prebendalism (Joseph, 1987), politics of the belly or stomach infrastructure (Bayart, 1993; Osaghae, 2003), and instrumentalisation of informal politics (Chabal \& Daloz, 1999). These perspectives on political leadership in Africa vary from the "criminalisation" of the state to political leadership as "dispensing patrimony", the "recycling" of elites and the use of state power and resources to consolidate political and economic power (Van Wyk, 2007, p. 3). Thus, politics rather than 
administrative processes are fundamental to overall development lapses including administrative effectiveness, hence Crocker (2019) posits that in Africa, it is the quality and characteristics of politics that shape the level of peace and stability and the prospects for economic development; it is governance at that level which determines whether there are durable links between the state and the society it purports to govern.

The prevailing misdemeanor of the African political elites can be categorized into two areas, namely, the politicisation of the society and the administrative system, and the failure in their governance responsibilities. In Tanzania, for example, Mfuru, Sarwatt \& Kanire (2018) observe that politicians interfere unnecessarily in public administration matters, exploit other public officials, and encourage societies to engage in demonstrations and agitations for narrow political gains. Similarly, in Nigeria, politicians use ethnic and clientelistic linkages as political and electoral instruments, for resource allocation and appointments. Civil society organisations can be 'purchased' to achieve political support even when it is obvious that the government or its action is misguided. Politicians hire paid mobs to counter genuine demonstrations or agitations to provide apparent legitimacy or protect narrow interests. Thus, in the country there are always public demonstrations for or against any issue no matter how obvious the truth seems. Politicisation of the administrative system through patronage and nepotism in Nigeria is the norm rather than the exception, to say the least (Ukpong 2018; Fasan, 2019). When the administrative institution and the society are politicised in this way, chances for corruption increase and the appointments to key posts are made not on the basis of merit but on extraneous considerations (Bendor, Daniel \& Michael, 2003; Mfuru, Sarwatt \& Kanire, 2018).

Apart from the issue of politicisation of the administrative system, civil societies and the society at large, it is important to also underline that political officials fail to a great extent in their primary role of governance. To economise space, we can only mention three key areas of this failure. These are ethnicity, corruption and disrespect for democratic norms and the rule of law. Ethnicity fans the embers of a national identity crisis, which relegates important values such as patriotism, justice and merit to the background. In countries like Nigeria, there are about four hundred ethnic nationalities which find it hard to co-exist. It is not so much the diversity that constitutes the challenge of ethnicity; rather, it is the absence of a sense of common identity and national consciousness among the groups and the exploitation of the primordial differences by politicians in the struggle for resources and other social interactions (Ikeanyibe, 2017; Ezeibe \& Ikeanyibe, 2017). This leads to balkanization rather than the building of political society. In Nigeria at present, Fasan (2019) avers that the country is reeling in the throes of age-long tribal politics, now made worse by the provincial instincts of a president who lacks the capacity to see the country beyond the constricted lenses of his small part of the richly diverse society. While ethnicity has always been a challenge to the governance of the country, it has been escalated in recent times as President $\mathrm{Bu}-$ hari's hitherto five years in office has witnessed the appointment of members of his Hausa/Fulani ethnic nationalities and Islamic northerners in key positions in government consequently heightening ethnic grievances, self-determination agita- 
tions, calls for restructuring of the country into regional powers and the practice of true federalism, and indeed recurrent divisions in the National Assembly along regional lines (Akhigbe, 2017; Krishi, 2018).

On the issue of corruption, despite the avowed declaration of subsequent political administrations to fight it, corruption has worsened in Nigeria. In the 2018 report by Transparency International (TI), the country was ranked 144 out of 180 countries surveyed. In the 2019 session, the country slipped to 146th position (The Cable, 2019) under the close watch of a government that made fighting corruption one of its key policy focuses during the electoral campaign in 2014. The head of TI has attributed worsening corruption in Nigeria to selective adherence to the rule of law and corruption in political parties (Channels Television, 2020). Evidence of corruption has been found much more among the class of politicians than the career officials in Nigeria (Ikeanyibe \& Ibietan, 2018).

It is important to highlight that because of the ethnic diversity in Nigeria, a policy of federal character (quota system) to ensure even distribution of resources and appointments was enshrined in Section 13, Subsection (3) of the 1999 Constitution of the Federal Republic of Nigeria which states that "the composition of the government of the federation or any of its agencies and the conduct of its affairs shall be carried out in such a manner as to reflect the federal character of Nigeria and the need to promote national unity, and also command national loyalty". By ignoring an important constitutional provision such as this, the rule of law is relegated to the background. Many other activities of the government defy the rule of law and other democratic norms. Thus executive license appears to be the trademark of the politicians with little self-assessment, competition towards improvement or strong indictment through any external peer review system. Innovation and learning is low as governments are not pushed to improve by developments recorded by their predecessors or governments elsewhere in Africa or other parts of the world.

One then wonders what role performance management has achieved at the level of politics or in terms of the role of politicians in governance. Obviously, finding ways to manage performance at that level is primary in Africa because this is the precursor of poor performance at the level of public organisations and other constituents of government and the society. The next section examines the practice of performance management at this level in Africa.

\section{Performance management, peer review and politics in Africa}

The most common way to problematize governance and policy failure in Nigeria, nay many countries of Africa, is to blame policy implementation. This is usually expressed in a maxim such as: 'the problem is not in formulating good policies but in their implementation.' Ikeanyibe (2013, p. 104) avers that "statements like this seem to throw the blame of policy failure on those policy implementing agencies." However, the role of politicians who should have responsibility over governance and policy making is not such a perfunctory one. Egonwan (2000, p. 155) provided numerous reasons why policies and government fail to provide deliverables to citizens. These include: inadequate definition of policy goals at the formulation stage, 
over ambitious policy goals, lack of a well-defined programme for the attainment of goals, choice of inappropriate organizational structure in implementing policies, lack of continuity in commitment to policy, lack of clear definition of responsibility, political opposition during implementation, compromises during implementation capable of defeating policy purposes, political insensitivity to demands necessary for implementation, factor of timing in implementation, corruption, and lack of adequate data on which decisions are predicated. Undoubtedly, key among these challenges are political roles that should by necessity be attributed to the level of policy formulation and attendant leadership in governance. Unfortunately, the application of PM at this level of governance is very weak.

The traditional approach to managing, measuring and rewarding the performance of the two classes of personnel in government - the politicians and the career officials - is fairly well known and effective in most western democracies. It is generally agreed in many polities that the politician has the duty of oversight over the administrator and administrative agencies. In many polities as well, elected and appointed politicians head administrative agencies and are considered their de jure managers. In this way, controls over policy implementation and staff performance could be established. Procedures for implementing performance management at this organizational level as we have seen include the use of the input-output relation underscoring the three interlinked elements of target-setting, performance measurement, and rewards and/or sanctions (Boyne, 2010). But it is quite obvious that political oversights and managers who should effect PM at the micro level of the organization are often incompetent and un-committed. Hence, administrative agencies are often left to drift like a rudderless ship. The US Department of State: Bureau of Democracy and Labour $(2018$, p.1) has rightly placed the blame on public organisation malfeasance while assessing some elections in Nigeria when it asserts that civilian authorities did not always maintain effective control over security agencies. This can be inferred of every other executive and administrative agency.

Aside from poor control over the administrative system expected of the political officials, we can also illustrate that the application of CAF elements of PM are weakly implemented in the African context. Citizen and civil society integration entails that performance management and reward of political officials are generally operated through power of removal of political appointees, impeachment of the chief executive by the legislature, recall of legislators by their constituencies, loss of elections in the next round for a non performing political party, civil society actions and so on. Although these methods are effective in controlling politicians in some climes, especially the west, they are not strongly institutionalized in Africa and some developing democracies. Despite the resoluteness of most citizens of African countries on the value of elections as a means of changing bad government, elections in some countries of Africa remain "political moments", which temporarily create greater uncertainty and heightened attention to politics, which can either lead to democratic gains or bring about regression (Bleck \& Van de Walle, 2019). In many instances, elections and related democratic means of controlling political leaders have remained very ineffective; elections are rigged and nonperforming politicians remain in office through manipulation of the constitution and elections, with little links to the citizens. Although some African countries are making slow 
progress in governance and democratic processes (see for instance Mo Ibrahim Index of African Governance, MIF, 2018), in many others autocracy, rent-seeking and what Westcott (2018) daubed the "Big Man challenge" remain entrenched and as strong as ever. Recent elections in the following countries - Cameroon, the Democratic Republic of Congo (DRC), Egypt, Madagascar, Mali, Sierra Leone, South Sudan and Zimbabwe in 2018, and Nigeria in 2019, attracted great apprehension. Most of these elections lived up to the fears. For instance, elections in Madagascar ended in violence with both presidential candidates claiming victory. In these elections, final electoral victories were only won in Court, which often depended much on technicalities rather than people's choice or votes. The Nigerian presidential election of 2019 is said to have been described by a former United States Ambassador to Nigeria as setting a bad example for democracy in Africa. He described the Nigerian democratic polity as a geriatric and unresponsive system whose patronage politics requires candidates to have vast sums of money and the ability to distribute them (Toromade, 2019). Apparently, a democratic system that is not responsive to citizens' electoral choice or votes does not promise the power of citizens to hold political officials accountable. This is apart from the direct consequences of such elections on political tension, divisiveness, crisis and violence (Nwokeke \& Jayum, 2011) and overall performance of government. Thus the usefulness of the partnership model is obviously weak in the majority of Africa, and performance management of the political class is in that measure non-existent.

The application of self-assessment and other components of the CAF are also glossily undermined and ineffective. Although African countries have tried establishing some kind of performance management initiatives to check the excesses of governments, practice and scholarship have often neglected their evaluation from the perspective of politics-administration distinction. At the continental level, the African Union (AU) introduced the African Peer Review Mechanism (APRM) as part of the New Partnership for African Development (NEPAD), similar to the Common Assessment Framework (CAF) of the European Union. The APRM was an initiative accepted in 2001 and ratified in the $38^{\text {th }}$ Ordinary Session of the AU in July 2002 (Suleman, Uys \& Reid, 2008). APRM is described as "a self-monitoring process focused on good governance to which countries commit themselves in order to foster the kind of practices that would lead to political stability, high economic growth, sustainable development and regional integration" (Ibid., p.36). The 2018 Continental Annual Reports of the APRM $(2019$, p. 5) explains that

The APRM facilitates good governance by promoting adherence to norms of conduct contained in the African Charter on Democracy, Elections and Governance (ACDEG). The Mechanism exists as a voluntary exercise between African Union States to systematically assess and review governance at Head of State peer level.

Like the CAF, APRM uses various performance targets under four key macro policy arenas, namely, democracy and political governance, economic governance, corporate governance, and socio-economic development, for performance assessment and peer review of countries. Many African countries have signed the APRM 
Memorandum of Understanding $(\mathrm{MoU})$ and subjected themselves to APRM peer reviews. Previous studies (Bing-Pappoe, 2010; Wani \& Suwirta, 2015; Fosu, 2017) acknowledge the necessity and the optimism of the APRM initiative as performance enhancing criteria. Individual country experiences differ as countries such as Rwanda and Ghana are acknowledged as having made progress. Bing-Pappoe (2010, p. 2) expresses some generally positive remarks although with strong reservations:

The overall picture is generally positive... Dialogue between stakeholders is occurring and changes are being introduced to the ways governments and countries are being run. There is peer learning, as experiences from one country are being introduced to others. But the pace of learning and the pace of change are slow.

This situation is also corroborated by the Mo Ibrahim Index of African Governance (Mo Ibrahim Foundation, MIF, 2018) ranking, which stated in its 2018 report that "overall governance in Africa remains, on average, on an upward trajectory. In 2017 the continent reached its highest governance score of the last ten years (2008-2017), 49.9 (out of 100.0), an improvement of +1.0 point from 2008 ". Despite this reality, progress has been driven by few countries. In truth, many countries manifest irregularities as progress suddenly went into reverse gear. Even gloomier is the fact that countries that had previously shown improved performance showed a deterioration. $\operatorname{MIF}(2018, \mathrm{p}$. 17) reports that

34 countries, home to approximately three out of four Africans (71.6\% of Africa's citizens), have improved their governance performance over the last ten-year period. It does leave, however, at least one in four Africans (27.2\%) experiencing decline in governance as 18 countries register a deteriorated score over the last ten years.

In said report, only a few countries, namely Kenya (moved from 19th to 11 th), Morocco ( $25^{\text {th }}$ to 15 th $)$ and Côte d'Ivoire (41st to $22 \mathrm{nd}$ ) drove the progress recorded in African governance improvement, while others showed marginal improvement. It is appalling that countries such as Botswana, Mauritius, and Cape Verde, usually cited as African countries that have shown a marked difference in political and administrative development (Englebert, 2000; Ikeanyibe, 2017), were among those ranked as having shown increasing deterioration (MIF, 2018, p. 16). In a nutshell, there is little performance management system at the level of governance to sustain progress in many countries.

Understandably, the reality of irregularity and deterioration could be revealed in the way countries subject themselves to self-assessment, peer review and competitiveness. The submission of countries to the APRM peer review framework, for instance, has been poor. Only 21 countries have been base-peer reviewed and only 11 have had at least one progress report (APRM, 2018). It is not by accident that out of the 37 member countries that have signed the APRM MoU as at December 2018, better performing countries in Africa such as Ghana and Rwanda were countries that have taken their self-assessment and subsequent progress re- 
ports seriously. Ghana has had six progress reports in addition to the initial peer review, while Rwanda, South Africa, Burkina Faso and Uganda have had three progress reports. These countries in reference to the MIF (2018) report were also ranked as either increasing improvement (Ghana, Burkina Faso, Uganda), slowing improvement (Rwanda) or bouncing back (South Africa). On the other hand, twenty-six (26) out of the thirty-seven (37) countries that signed the APRM memorandum have not submitted themselves to any single self-assessment, and include such high risk countries as Congo, Chad, Liberia, Mali, Niger, Sierra Leone and Sudan (Africa’s self-assessment for good governance, https://www.aprm-au. $\mathrm{org} / \mathrm{fr} / \mathrm{map}$-areas/). Most of these countries also are ranked poorly in the MIF (2018) report, with a good number of them showing warning signs. There is therefore high proportionality of a country's commitment to APRM review and other performance measures towards improved governance. For instance, Kenya, which is presented as one of the countries that drove progress in the 2008-2017 governance progress in Africa (MIF, 2018), is described in the APRM (2017, p. 14) report thus: "only Kenya has explored uncharted territory and singled itself out by becoming the first ever country to undergo a second type of review". The second type of review has to do with a review requested by the member country itself rather than five year statutory ones which are not met by many countries.

For a good number of countries that have subjected themselves to APRM review, Matlosa (2014, p.16) observes that there has been poor implementation of the National Programme of Actions (NPoAs). He averred that "reviewed countries have generally done poorly in ensuring effective implementation of NPoAs and the APRM Secretariat, in turn, has not yet developed effective monitoring and evaluation instruments to assess how countries are doing in respect of the implementation of NPoAs. NPoAs consist of a programme of actions based on information generated from conducted peer review. Obviously, when peer review and assessment results are not implemented and monitored, they serve no useful purpose as PM tools.

At the political level, PM features should come through committed self-assessment, competition and externally imposed ranking, monitoring and disapproval by peers or international communities. Incidentally, numerous international bodies have come up with different global performance indicators such as the MIF, World Bank ease of doing business, Transparency International, Terrorism index and a host of others. To a large extent decision-makers have come to view the global performance rankings such as the ease of doing business index as a system that compares performance, engages reputations, and incites competition (Kelley, 2017). However, the challenge is how these various measuring and ranking initiatives are rewarded or sanctioned to form strong peer and 'social pressure' (Doshi, Kelley \& Simmons, 2019, p. 2) that constitute rewards/sanctions in the PM process. Some countries including Nigeria have usually shown mixed feelings about these rankings, praising and legitimising their efforts when ranking favours them, and rejecting it when it is not favourable. This is to say that commitment certainly fluctuates as ranking and opinions about governance efforts do not in effect serve as valid performance information that should guide corrections in specific governance issues. In most situations, governments in Africa portray a self-righteous approach and adopt self -praise and thus fail to appreciate the merits of PM information. 
For Nigeria particularly, Jinadu (2008) remarked that there is slow implementation of NPoA and the national APRM institutions are highly dependent on the federal executive leaving room for doubt regarding reports and self-assessments. The country acceded to APRM in 2003 and had the first peer review in 2008. Although Nigeria had two progress reports in 2009 and 2011, little has been done thereafter. APRM peer review ought to take place in five year intervals (PM News, 2019). Thus, Nigeria is overdue a peer review by the APRM secretariat and indeed the internal self-assessment review that yields the progress report.

From the forgoing, it is suggestive that much of the rot in most African countries, Nigeria inclusive, emanates and thrives at the political level. The political officials have not been above board and as the US Department of State: Democracy and Labor (2018) submits, did not always maintain effective control over the administrative system. It is the political officials who, to a large extent, have the power of policy and programme authorization, funding and empowerment for implementation, and the overall control of the bureaucracy. Unfortunately, the implementation of PM at this level has been shown to be quite irregular, non-committed and perfunctory, missing the critical principles of performance management that ensure not just setting targets, but measuring performance and rewarding or sanctioning accordingly. With poor linkage of politics to citizens and the electorates in Africa to ensure what James and John (2007) describe as electoral penalty, there are still no strong instruments to enforce and monitor PM at this level. The National Performance Management Advisory Commission (2010) noted that it would require public sector leaders at all levels, both elected and appointed, not only to set high expectations for performance but also to make a commitment to improving performance. Although the APRM and other global and regional performance ranking indicators have established mediums for peer review, self-assessment and competitiveness to enhance politics in Africa, commitment to their use, and the means of enforcing reward and sanction remain suboptimal.

\section{Concluding Remarks}

This study examined how the contextually specific assumptions underlying performance management could be understood in relation to the political officials in government in the African context based on the notion of politics-administration dichotomy and the assumed leadership/governance role of the political class in that relationship. Specifically, the study investigated how the specific assumptions of performance management should be understood in relation to the political class in government and how the role of political officials affect the performance of government in Africa, with a focus on Nigeria. The Common Assessment Framework which underscores the role of leadership in relation to other inputs - peer review, self-assessment, competitive approach and innovation and learning - which provide results in performance management, was used as the analytical framework. Based on this, the study examined how the African Peer Review Mechanism and similar global and regional performance ranking indicators have served to provide performance information and redress for African countries. The authors found that although these provide useful mediums for peer 
review, competition, innovation and learning, and self-assessment, countries have not been fully committed to the subjection and use of such PM tools. The study found that Nigeria, like many countries of the African Union, have not taken the issue of sustained self-assessment and peer review seriously. Subjection to peer review, which normally should be on five year-round, last took place in Nigeria in 2008, thus now being about twelve (12) years overdue. More importantly, the African Union through the APRM Secretariat has not yet developed effective monitoring and evaluation instruments to assess how countries are doing in respect of the implementation of NPoAs (Matlosa, 2014).

Although some experts (see, for example, Tawfic, 2004) have expressed doubt in the workability of peer review mechanism in Africa, the authors think that sustaining regular and consistent peer review and self-assessment through internal and external enforcement of compliance will be a path to credible commitment for Nigerian and indeed African politicians. With this submission, the study suggests international donors paying greater attention to political reforms and using information from various global ranking indices as conditions in their bilateral/multilateral assistance, and as an instrument of subtle compulsion to support and strengthen African countries to commit peer review, self-assessment, competition and innovation and learning in governance. There is also a clear indication that the African Union APRM Secretariat needs enlarged financial and moral support to intensify, strengthen and sustain its programme of the peer reviewing of countries more frequently.

\section{REFERENCES}

1. Adsera, A., Boix, C. \& Payne, M. (2003). Are You Being Served? Political Accountability and Quality of Government. The Journal of Law, Economics and Organisation, vol. 19, no 2, pp. 445-490.

2. Akhigbe, N. (2017). Fact-Check: 81 of Buharis 100 Appointees Are Northerners. Business Day. Available at: https://businessday.ng/backpage/article/fact-check-81-buharis-100-appointeesnortherners/ (accessed: 11 June, 2020).

3. Amoda, J. (2012). Review of the Concept of Peer Review Mechanism. Vanguard. June,12. Available at: https://www.vanguardngr.com/2012/06/review-of-the-concept-of-peer-reviewmechanism/ (accessed: 11 June, 2020).

4. Andrews, R. (2014). Performance Management and Public Service Improvement: Evidence Review Prepared for the Commission on Public Service Governance and Delivery. Public Policy Institute of Wales, PPIW Report No. 3.

5. Armstrong, M. \& Baron, A. (2005). Managing Performance: Performance Management in Action. London: Chartered Institute of Personnel and Development.

6. Ayee, J. (2005). Public Sector Management in Africa. Economic Research Working Paper, 82. Tunisia: African Development Bank. Available at: http\%3A\%2F\%2Fwww.afdb.org\%2Ffilead min\%2FPublications\%2F00457499-EN-ERWP82.PDF (accessed: 11 June, 2020). 
7. Azunu, R. (n/d). Politics-Administration Relations in Developing Countries: Lessons from Ghana's Local Government.

8. Bayart, J-F. (1993). The State in Africa: The Politics of the Belly. New York: Longman.

9. Bleck, J. \& Van de Walle, N. (2019). Change and Continuity in African Electoral Politics Since Multipartyism. Oxford Research Encyclopedia of Politics Available at: DOI:10.1093/ acrefore/9780190228637.013.741 (accessed: 11 June, 2020).

10. Bendor, J., Daniel, D. \& Michael, T. (2003). A Behavioral Model of Turnout. American Political Science Review, no 97, pp 261-80.

11. Bing-Pappoe, A. (2010). Reviewing Africa's Peer Review Mechanism: A Survey of Seven Countries. Ottawa, Ontario, Canada: Partnership Africa Cananda Partnership.

12. Bleck, J \& Van de Walle, N. (2019). Change and Continuity in African Electoral Politics Since Multipartyism. Oxford Research Encyclopedia of Politics. Available at: DOI:10.1093/ acrefore/9780190228637.013.741 (accessed: 11 June, 2020).

13. Boyne, G.A. (1996). The Intellectual Crisis in British Public Administration: Is Public Management the Problem or the Solution? Public Administration, no 74 (Winter), pp. 679-694.

14. Bratton, M. \& Van de Walle, N. (1994). Neopatrimonial Regimes and Political Transitions in Africa. World Politics, vol. 46, no 4.

15. Chabal, P. \& Daloz, J.-P. (1999). Africa Works: Disorder as Political Instrument. Indiana: The International African Institute and Indiana University Press.

16. Channels Television (2020). Why Nigeria was Ranked Low in Corruption Index - Transparency International. Available at: https://www.channelstv.com/2020/01/23/transparencyinternational-scores-nigeria-low-on-corruption-perception-index/ (accessed: 24 January, 2020).

17. Chukwumerije, O. (2006). Peer Review and the Promotion of Good Governance in Africa. North Carolina Journal of International Law and Commercial Regulation, vol. 32, no 1, pp. 46-114.

18. Cook, B. (2004). The Managing of the (Third) World. Organization, vol. 11, no 5, pp. 603-629.

19. Crocker, C.A. (2019). African governance: Challenges and Their Implications. Governance in an Emerging World, Winter Series, no 119. Available at: https://www.hoover.org/research/ african-governance-challenges-and-their-implications (accessed: 11 June, 2020).

20. Demir, T. (n/d). Politics and Administration: A Review of Research and Some Suggestions. Available at: http://fau.edu/spa/pdf/Demir_PoliticsandAdministration_New_MS.pdf

21. Doshi, R., Kelley, J.G. \& Simmons, B.A. (2019). The Power of Ranking: The Ease of Doing Business Indicator and Global Regulatory Behavior. International Organization, vol 73, no 3, pp. 611-643.

22. Egonmwan (2000). Public Policy Analysis: Concepts and Applications. Benin City: Resyi Nig Company.

23. Ekeh, P. P. (1975). Colonialism and the Two Publics: A Theoretical Statement. Comparative Studies in Society and History, vol. 17, no 1, pp. 1-112.

24. Englebert, P. (2000). Pre-Colonial Institutions, Post-Colonial States, and Economic Development in Tropical Africa. Political Research Quarterly, vol. 53, no 1, pp. 7-36. 
25. Ezeibe, C.C. \& Ikeanyibe, O.M. (2017). Ethnic Politics, Hate Speech, and Access to Political Power in Nigeria. Africa Today, vol. 63, no 4 (Summer 2017), pp. 65-83. Available at: http:// www.jstor.org/stable/10.2979/africatoday.63.4.04 (accessed: 31 July, 2017).

26. Fasan, R. (2019). Muhammadu Buhari and Nigeria’s Tribal Politics. Vanguard. Available at: https://www.vanguardngr.com/2019/01/muhammadu-buhari-and-nigerias-tribal-politics/ (accessed: 11 June, 2020).

27. Finer, H. (1941). Administrative Responsibility in Democratic Government. Public Administration Review, no 1, pp. 335-350. Reprinted in Francis Rourke, ed. Bureaucratic Power in National Politics. 3d ed. Boston: Little, Brown, 1978.

28. Frederickson, G.H. (1980). New Public Administration. University of Alabama Press.

29. Friedrich, C. (1940). Public Policy and the Nature of Administrative Responsibility. Public Policy, no 1, pp. 3-24. Reprinted in Francis Rourke, ed. Bureaucratic Power in National Politics. 3d ed. Boston: Little, Brown, 1978.

30. Fosu, A.K. (2017). Governance and Development in Africa: A Concise Review. GDI Working Paper 2017-008. Manchester: The University of Manchester.

31. Heady, F. (1984). Public Administration: A Comparative Perspective. New York: Marcel Dekker, Inc.

32. Holmstrom, B. (1982). Moral Hazard in Teams. Bell Journal of Economics, no 13, pp. 32-40.

33. Hoskisson, R.E., Eden, L., Lau, C.M. \& Wright, M. (2000). Strategy in Emerging Economies. Academy of Management Journal, vol. 43, no 3, pp. 249-267.

34. Hyden, G. (1983). No Shortcuts to Progress: African Development Management in Perspective. Berkeley: University of California Press and London: Heinemann Educational Books.

35. Ikeanyibe, O.M. (2013). Public Policy in Nigeria: Perspectives on Social Policy. Enugu: John Jacob’s Classic Publishers Ltd.

36. Ikeanyibe, O.M. (2017). Bureaucratization and Administrative Development in Africa: A Reading of Riggs' Theory of Prismatic Society. Public Admin Development, vol. 37, no 5, December, pp. 307-318. Available at: https://doi.org/10.1002/pad.1816 (accessed: 11 June, 2020).

37. Ikeanyibe, O. \& Ibietan, J. (2018). The Effect of Pay and Administrative Control on Ethical Behaviour in the Nigerian Public Service. Public Administration Issues, Special Issue II (electronic edition), pp. 24-44 (in English). Available at: doi: 10.17323/1999-5431-2018-0-6-24-44 (accessed: 11 June, 2020).

38. Jacobsen, D.I. (2001). Are the Relations Between Politicians and Administrators at the Local Level Determined by the Degree of Central Government Regulations? Paper presented at the ECPR Joint Sessions of Workshops, Grenoble, April. Theme: Workshop no 21: "Local Autonomy and Local Democracy".

39. James, O. \& John, P. (2007). Public Management at the Ballot Box: Performance

40. Information and Electoral Support for Incumbent English Local Governments. Journal of Public Administration Research and Theory, vol. 17, no 4, pp. 567-580.

41. Jinadu, L.A. (208). The African Peer Review Process in Nigeria. Eldis. Available at: https:// www.eldis.org/document/A51598 (accessed: 11 June, 2020).

42. Joseph, R. (1997). Prebendalism and Democracy in Nigeria. New York: Cambridge University Press. 
43. Kalfa, M. \& A. Yetim, A. (2018). Organizational Self-Assessment Based on Common Assessment Framework to Improve the Organizational Quality in Public Administration. Total Quality Management \& Business Excellence. Available at: doi: 10.1080/14783363.2018.1475223 (accessed: 11 June, 2020).

44. Kelley, J (2017). Scorecard Diplomacy: Grading States to Influence Their Reputation and Behavior. Cambridge: Cambridge University Press.

45. Krishi, M.A. (2018). Senators in Rowdy Session Over Buharis' 'Skewed'. Daily Trust. Appointments. Available at: https://www.dailytrust.com.ng/senators-in-rowdy-session-over-buharis-skewed-appointments-261850.html (accessed: 11 June, 2020).

46. Matlosa, K. (2014). Pan-Africanism, the African Peer Review Mechanism and the African Charter on Democracy, Elections and Governance: What does the future Hold? South African Institute of International Affairs.

47. Lipsky, M. (1980). Street-Level Bureaucracy: Dilemmas of the Individual in Public Services. In: Hill, M. The Policy Process: A Reader, pp. 389-92. London: Prentice Hall/Harvester Wheatsheaf.

48. Martin, D.W. (1988). The Fading Legacy of Woodrow Wilson. Public Administration Review, vol. 48, no 2, pp. 631-636.

49. Maurel, C., Carassus, D., Favoreu, C. \& Gardey, D. (2014). Characterization and Definition of Public Performance: An Application to Local Government Authorities. Revue Gestion et Management Public, vol. 2, no 3, pp. 23-44.

50. McKinsey Global Institute (2010). Lions on the move: The progress and potential of African economies. Available at: http://www. mckinsey.com/insights/africa/lions_on_the_move (accessed: 30 November, 2019).

51. Mfuru, A.W.E Sarwatti, A.C. \& Kanire, G. (2018). The Impact of Political Interference in Public Administration in Kibaha Town Council. Global Journal of Political Science and Administration, vol.6, no 4, pp. 21-31.

52. Miller, G. (2000). Above Politics: Credible Commitment and Efficiency in the Design of Public Agencies. Journal of Public Administration Research and Theory, vol. 10, no 2, pp. 289-327.

53. National Performance Management Advisory Commission (2010). A Performance Management Framework for State and Local Government: From Measurement and Reporting to Management and Improving. Chicago, Illinois: National Performance Management Advisory Commission.

54. Nwokeke, P.O. \& Jayum, A. J. (2011). The Electoral Process and Democratic Consolidation in Nigeria. Journal of Politics and Law, vol. 4, no 2, pp. 128-138.

55. Nnoli, O. (2008). Ethnic Politics in Nigeria. 2nd ed. Enugu: Pan African Centre for Research on Peace and Conflict Resolution.

56. Osaghae, E.E. (2003). Colonialism and Civil Society in Africa: The Perspective of Ekeh's Two Publics. Paper presented at the Symposium on Canonical Works and Continuing Innovation in African Arts and Humanities, Accra, Ghana, 17-19 September 2003.

57. Osterreich, B. (2006). The Common Assessment Framework (CAF). Improving an Organization Through Self-Assessment. Paper presented at the $4^{\text {th }}$ Quality Conference for Public Administrations in the EU. 
58. Panday, P. (2017). Bureaucracy and Politicians: Dynamics and Challenges. In: Ali Farazmand (ed.) Global Encyclopedia of Public Administration, Public Policy and Governance. Available at: https://link.springer.com/referenceworkentry/10.1007\%2F978-3-319-31816-5_3293-1 (accessed: 30 March, 2019).

59. Peters, B.G. (1987). Politicians and Bureaucrats in the Politics of Policy-Making. In: J.E. Lane (ed.). Bureaucracy and Public Choice. London: SAGE Publications, pp. 256-282.

60. News (2019). Nigeria to Undergo 2nd Peer Review after 11 Years. Available at: https://www. pmnewsnigeria.com/2019/05/24/nigeria-to-undergo-2nd-peer-review-after-11-years/ (accessed: 11 June, 2020).

61. Rabrenovic, A. (2001). Review of Theory on Politico-Administrative Relations. In: Tony Verheijen (2001). Politico-Administrative Relations: Who Rules? Bratislava, Slovak Republic: The Network of Institutes and Schools of Public Administration in Central and Eastern Europe, NISPACEE, pp. 11-25.

62. Rouban, L. (2003). Politicization of the Civil Service. In: B. Peters and J. Pierre (eds), Handbook of Public Administration. London: Sage, pp. 310-320.

63. Sancino, A. Meneguzzo, M., Braga, A. \& Esposito, P. (2018). The Relationship between Politics and Administration. In: Richard Kerley, Joyce Liddle, Pamela T. Dunning (eds.). The Routledge Handbook of International Local Government, pp. 70-81. Available at: https:// www.routledgehandbooks.com/doi/10.4324/9781315306278-6 (accessed: 22 October, 2018).

64. Suleman, F., Uys, L. \& Reid, S. (2008). The African Peer Review Mechanism: The South African Experience of Health Academics. Africa insight, vol. 38, no 2, pp. 36-49.

65. Svara, J.S. (2001). The Myth of the Dichotomy: Complementarity of Politics and Administration in the Past and Future of Public Administration. Public Administration Review, vol. 61, no 2, pp. 176-183.

66. Svara, J.H. (1985). Dichotomy and Duality: Reconceptualizing the Relationship between Policy and Administration in Council-Manager Cities. Public administration Review, no 45, pp. 221-232.

67. Tawfic, R. (2004). Reviewing good Governance Towards a Methodology for the African Peer Review Mechanism. The South African Institute of International Affairs Report No 41.

68. The Cable News (2020). Nigeria Ranked Second 'Most Corrupt' ECOWAS Country on TI Corruption Index (Updated). Available at: https://www.thecable.ng/breaking-nigeria-ranks-loweron-transparency-internationals-corruption-index (accessed: 24 January, 2020).

69. Toromade, S. (2019). Nigeria's 2019 Presidential Election Bad for Democracy in Africa, Ex-US Ambassador says. Pulse. Available at: https://www.pulse.ng/news/politics/nigerias-2019-electionbad-for-democracy-john-campbell-says/42lk5pp (accessed: 11 June, 2020).

70. Ugyel, L. (2017). Relationship between Politics and Administration in Pacific Island.

71. Governmental Systems. Available at: https://devpolicy.org/relationship-politics-administrationpacific-island-governmental-systems-20170908/ (accessed: 3 January, 2019).

72. Ukpong, C. (2019). Analysis: Between Buhari the Military Dictator and Buhari the 'Reformed Democrat'. Premium Times. Available at: https://www.premiumtimesng.com/featuresand-interviews/368143-analysis-between-buhari-the-military-dictator-and-buhari-thereformed-democrat.html (accessed: 11 June, 2020).

73. United States Department of State Bureau of Democracy Human Rights and Labor (2019). Nigeria 2018 Human rights report. 
74. Van Wyk, J. (2007). Political Leaders in Africa: Presidents, Patrons or Profiteers? The African Centre for the Constructive Resolution of Disputes (ACCORD). Occasional Paper, Series, vol. 2 , no 1 .

75. Verheijen, T. (2001). Politico-Administrative Relations: Who Rules? (Ed.). Bratislava, Slovak Republic: The Network of Institutes and Schools of Public Administration in Central and Eastern Europe, NISPACEE.

76. Von Holdt, K. (2010). Nationalism, Bureaucracy and the Developmental State: The South African Case. South African Review of Sociology, vol. 41, no 1, pp. 4-27.

77. Wani, H.A. \& Suwirta, A. (2015). Changing Dynamics of Good Governance in Africa. International Journal for Educational Studies, vol. 7, no 2, pp. 189-220.

78. Westcott, N. (2018). Africa's 2018 Elections: The Good, the Bad and the Possibly Not-At-All. African Arguments. Available at: https://africanarguments.org/2018/01/24/africas-2018elections-the-good-the-bad-and-the-possibly-not-at-all/ (accessed: 11 June, 2020).

79. Williams, D. (2003). Measuring Government in the Early Twentieth Century. Public Administration Review, vol. 63, no 6, pp. 643-658.

80. Wilson, W. (1887). The Study of Administration. Political Science Quarterly, vol. 2, no 2, pp. 197-222.

81. World Bank $(1993,1993)$. The East Asian Miracle: Economic Growth and Public Policy. New York: Oxford University Press.

82. Zoogah, D., Peng, M. \& Woldu, H. (2015). Institutions, Resources and Organizational Effectiveness in Africa. The Academy of Management Perspectives, vol. 29, no 1, pp. 7-31.

\section{OFFICIAL DOCUMENTS}

1. African Peer Review Mechanism (2009). APRM Country Review Report, no 8, Federal Republic of Nigeria.

2. African Peer review Mechanism (APRM). (2018). 2017 APRM Annual Reports.

3. African Peer Review Mechanism (APRM). (2019). 2018 APRM Annual Continental Reports, Africa's Self-Assessment for Good Governance Continental Presence. Available at: https:// www.aprm-au.org/fr/map-areas/ (accessed: 11 June, 2020).

4. Federal Republic of Nigeria (1999). 1999 Constitution of the Federal Republic of Nigeria Lagos: Federal Government Press.

5. Federal Republic of Nigeria (Presidency) (2011). New Partnership for Africa's Development: African Peer Review Mechanism: Second Progress Report on the Implementation of the National Programme of Action of the Federal Government of Nigeria.

6. Mo Ibrahim Foundation (MIF) (2018). 2018 Ibrahim Index of African Governance. 